\title{
Comparison of Work Values between Staff in Tourism Industry and Students in Tourism Universities
}

\author{
Lijun Jiang \\ Guilin Tourism University, Guilin Guangxi, 541006, China
}

Keywords: tourism staff; tourism college students; work values

\begin{abstract}
Adopting the WVI (work values inventory) by Ning Weiwei, the author carried out a research about the work values among the students of four tourism universities and staff in 35 tourism enterprises. From the perspectives of the related influencing factors and priorities, this paper has found that the work values of tourism students are mainly affected by their major and attitude towards major while those of the tourism staff are affected by their professional titles and job positions. The influential factors are prioritized as life style, academic achievement, economic payment, colleague relationship and independence for the former, while career achievement, colleague relationship, supervision relationship, life style and reputation for the latter. The differences of work values between these two groups lie in the following influential factors: achievement, independence, altruism, colleague relationship and supervision.
\end{abstract}

\section{Introduction}

2017 national tourism work conference was convened in Changsha on January 12. According to the measurement and calculation of UN World Tourism Organization, in 2016, the comprehensive contribution of China's tourism to national economy reached $11 \%$; the comprehensive contribution of China's tourism to social employment exceeded $10.26 \%$, basically the same with world average level. "Tourism leisure upgrading action" in China has become an important content of "top 10 consumption expansion actions". Peng Decheng - the director of Planning Finance Department of National Tourism Administration said, "Tourism has become a new engine to stimulate economic growth". The rapid development trend of tourism should have brought the expansive employment prospect, but tourism talent development in China presents the following features: shortage of talent supply, lack of senior talents, too fast talent turnover and insufficient talent training, etc. These features seriously hinder the healthy development of China's tourism. High-level talents do not want to enter in this industry, which also becomes an important problem troubling administrators of tourism enterprises. Understanding vocational values of tourism talents is the precondition of attracting excellent talents in the tourism and improving quality of tourism talents. Vocational choice is determined by individual vocational values.

\section{Research object and method}

\subsection{Research object}

The research objects include students and employees. The students majoring in tourism were chosen from four universities. 750 questionnaires were distributed, and 697 effective questionnaires were collected.

The enterprise employees were chosen from different types of tourism enterprises. 35 tourism enterprises of four types were visited. 250 questionnaires were distributed, and 197 effective questionnaires were collected. The sample composition is shown in Tab.1: Sample Composition Table. 
Tab.1: Sample Composition Table

\begin{tabular}{|c|c|c|c|c|}
\hline Total samples & & & Number of samples & Proportion \\
\hline \multirow{14}{*}{$\begin{array}{l}\text { Students } \\
\text { (697) }\end{array}$} & \multirow[t]{2}{*}{ Gender } & Male & 206 & 29.6 \\
\hline & & Female & 491 & 70.4 \\
\hline & \multirow{4}{*}{$\begin{array}{l}\text { Senior class } \\
\text { Junior class }\end{array}$} & Fresh year & 121 & 17.4 \\
\hline & & Sophomore year & 201 & 28.8 \\
\hline & & Junior year & 340 & 48.8 \\
\hline & & Senior year & 35 & 5.0 \\
\hline & \multirow[t]{6}{*}{ Major } & Hotel & 108 & 15.5 \\
\hline & & $\begin{array}{c}\text { Tourism } \\
\text { management }\end{array}$ & 342 & 49.1 \\
\hline & & Leisure & 71 & 10.2 \\
\hline & & Foreign language & 103 & 14.8 \\
\hline & & Traffic & 43 & 6.2 \\
\hline & & $\begin{array}{c}\text { Scenic area } \\
\text { planning }\end{array}$ & 30 & 4.3 \\
\hline & \multirow[t]{2}{*}{ Internship } & No & 343 & 49.2 \\
\hline & & Yes & 354 & 50.8 \\
\hline \multirow{10}{*}{$\begin{array}{c}\text { Employees } \\
\text { (197) }\end{array}$} & \multirow[t]{2}{*}{ Gender } & Male & 77 & 39.1 \\
\hline & & Female & 120 & 60.9 \\
\hline & \multirow[t]{4}{*}{ Position } & Common employee & 92 & 46.7 \\
\hline & & Supervisor & 54 & 27.4 \\
\hline & & Manager & 28 & 14.2 \\
\hline & & General manager & 23 & 11.7 \\
\hline & \multirow[t]{4}{*}{ Post } & Hotel & 66 & 33.5 \\
\hline & & Scenic area & 57 & 28.9 \\
\hline & & Golf & 31 & 15.7 \\
\hline & & $\begin{array}{c}\text { Second-level } \\
\text { department }\end{array}$ & 43 & 21.8 \\
\hline \multicolumn{3}{|c|}{ Total number } & \multicolumn{2}{|l|}{894} \\
\hline
\end{tabular}

\subsection{Research tool}

Questionnaire method was applied. The test tool is work values inventory (WVI) modified by Ning Weiwei. He divided occupational values into three dimensions (internal value, external value and external remuneration) and 15 scales. There were 15 value scales under each dimension. Each value scale included 4 items.

SPSS17.0 for Windows was used for statistical analysis of data.

\section{Survey result}

\subsection{Evaluation of vocational value dimensions by tourism-related college students under different individual background}

Tab. 2 shows that, in $\mathrm{T}$ test, tourism-related college students have no difference in the three di9mensions (internal value, external value and external remuneration) under the background of gender, grade and internship. The mean value shows that different gender and grade have no difference in the sorting. The order (descending order) is as follows: external remuneration, internal value, external value. Seeing from the internship, the sorting has differences for the students with and without internship experience. For the students with internship experience, their value dimension 
sorting is as follows: internal value, external remuneration, external value. For the students without internship experience, their value dimension sorting is as follows: external remuneration, internal value, external value. The students after the internship more value internal value.

Tab. 3 shows that, in terms of major background, tourism-relate college students have differences in the three dimensions (internal value, external value and external remuneration). For the college students of hotel major and traffic major, their sporting is as follows: external remuneration, external value, internal value. For the college students of tourism management major and foreign language major, their sporting is as follows: external remuneration, internal value, external value. For the college students of leisure major and scenic area major, their sporting is as follows: internal value, external remuneration, external value. Under the background of attitude to the major, the students liking and disliking the major have significant differences in remuneration dimension. Seeing from the sorting, the students liking the major value internal value more than those disliking the major.

Tab.2: Comparison of vocational value dimension evaluation by tourism-related college students under different background

\begin{tabular}{|c|c|c|c|c|}
\hline \multicolumn{2}{|c|}{ Personal background } & Internal value mean & External value mean & $\begin{array}{c}\text { External remuneration } \\
\text { mean }\end{array}$ \\
\hline \multirow{3}{*}{ Gender } & Male & 3.8226 & 3.7427 & 3.8741 \\
\cline { 2 - 5 } & Female & 3.9677 & 3.9439 & 4.0502 \\
\cline { 2 - 5 } & sig. & .053 & .076 & .534 \\
\hline \multirow{3}{*}{ Grade } & Senior class & 3.9428 & 3.8838 & 3.9607 \\
\cline { 2 - 5 } & Junior class & 3.9038 & 3.8851 & .528 \\
\cline { 2 - 5 } & sig. & .071 & 3.8933 & 3.9476 \\
\cline { 2 - 5 } & Yes & 3.9500 & 3.8774 & .0379 \\
\cline { 2 - 5 } & No & 3.9049 & .466 & .304 \\
\hline
\end{tabular}

Sig. is concomitant probability in T test; the value $*<.05 * *<.01 * * *<.001$

Tab.3: Comparison of students’ vocational value dimension based on different major and attitude to the major

\begin{tabular}{|c|c|c|c|c|}
\hline \multicolumn{2}{|c|}{ Personal background } & \multirow{2}{*}{$\begin{array}{c}\text { Internal value mean } \\
3.9573 \\
\end{array}$} & \multirow{2}{*}{$\begin{array}{c}\text { External value mean } \\
4.0440\end{array}$} & \multirow{2}{*}{$\begin{array}{c}\begin{array}{c}\text { External remuneration } \\
\text { mean }\end{array} \\
4.1071 \\
\end{array}$} \\
\hline Major & Hotel & & & \\
\hline & $\begin{array}{c}\text { Tourism } \\
\text { management }\end{array}$ & 3.8652 & 3.8257 & 3.9578 \\
\hline & Leisure & 4.0135 & 3.8706 & 3.9111 \\
\hline & $\begin{array}{l}\text { Foreign } \\
\text { language }\end{array}$ & 3.9577 & 3.8786 & 4.0273 \\
\hline & Traffic & 4.0947 & 4.1017 & 4.2122 \\
\hline & $\begin{array}{l}\text { Scenic area } \\
\text { planning }\end{array}$ & 3.9202 & 3.7208 & 3.8646 \\
\hline & sig. & $.050 *$ & $.001^{* *}$ & $.006 *$ \\
\hline \multirow{3}{*}{$\begin{array}{c}\text { Attitude to } \\
\text { major }\end{array}$} & Like & 3.9639 & 3.9069 & 3.9998 \\
\hline & Dislike & 3.7516 & 3.7753 & 3.9766 \\
\hline & sig. & .187 & .090 & $.019 *$ \\
\hline
\end{tabular}

\subsection{Evaluation of vocational value dimensions by tourism enterprise employees under different background}

Tab.4 shows that, under gender background, tourism enterprise employees have no significant difference in the three dimensions (internal value, external value and external remuneration). Seeing 
from the sorting, male employees more value internal value, while female employees more value external remuneration.

Under position background, tourism enterprise employees have significant differences in the two dimensions (external value and external remuneration). Seeing from the sorting, grassroots employees pay more attention to external remuneration, while the employees with the position of manager or above pay more attention to internal value.

Under post background, tourism enterprise employees have significant differences in the two dimensions (external value and external remuneration). Seeing from the sorting, hotel, golf and second-level employees pay more attention to external remuneration, while scenic area employees pay more attention to internal value.

Tab.4: Comparison of vocational value dimension evaluation by tourism enterprise employees under different background

\begin{tabular}{|c|c|c|c|c|}
\hline \multicolumn{2}{|c|}{ Personal background } & \multirow{2}{*}{$\begin{array}{c}\text { Internal value mean } \\
3.9525\end{array}$} & \multirow{2}{*}{$\begin{array}{c}\text { External value mean } \\
3.7881\end{array}$} & \multirow{2}{*}{$\begin{array}{c}\begin{array}{c}\text { External remuneration } \\
\text { mean }\end{array} \\
3.8929 \\
\end{array}$} \\
\hline Gender & Male & & & \\
\hline & Female & 4.1314 & 4.0896 & 4.1438 \\
\hline & Sig. & .107 & .251 & .043 \\
\hline \multirow[t]{5}{*}{ Position } & $\begin{array}{l}\text { Grassroots } \\
\text { employee }\end{array}$ & 4.0297 & 4.0394 & 4.1250 \\
\hline & Supervisor & 4.1346 & 4.0671 & 4.1470 \\
\hline & Manager & 4.1085 & 3.9107 & 3.9353 \\
\hline & General manager & 3.9599 & 3.5516 & 3.6250 \\
\hline & Sig. & .425 & $.000 * * *$ & $.001 * *$ \\
\hline \multirow[t]{5}{*}{ Post } & Hotel & 4.0723 & 4.0597 & 4.1345 \\
\hline & Scenic area & 4.0088 & 3.6820 & 3.7873 \\
\hline & Golf & 4.1377 & 4.1331 & 4.1794 \\
\hline & $\begin{array}{c}\text { Second-lien } \\
\text { posts of various } \\
\text { enterprises } \\
\end{array}$ & 4.0599 & 4.1047 & 4.1555 \\
\hline & Sig. & .703 & $.000 * * *$ & $.001 * *$ \\
\hline
\end{tabular}

3.3 Value dimension and scale comparison of tourism enterprise employees and tourism-related college students

Tab.5 shows that, tourism enterprise employees and tourism-related college students have no significant difference in the three dimensions (internal value, external value and external remuneration). Seeing from the sorting, students pay more attention to job remuneration than employees, while employees pay more attention to internal value.

Tab.6 shows that, the value scale sorting (descending order) of vocational values of tourism-related students is as follows: life style, achievement, economic return, relationship between colleagues, independence. The value scale sorting (descending order) of vocational values of tourism enterprise employees is as follows: achievement, relationship between colleagues, supervision relationship, life style and reputation.

Tab.7 shows that, in each scale of internal value, tourism enterprise employees and tourism-related college students have significant difference in the three scales (achievement, independence and altruism). This indicates that, employees pay more attention to achievement, independence and altruism than students. 
Tab.5: Value dimension comparison of tourism enterprise employees and tourism-related college students

\begin{tabular}{|c|c|c|c|}
\hline Value scale & Internal value mean & External value mean & Job remuneration mean \\
\hline Student & 3.9248 & 3.8844 & 4.0026 \\
\hline Employee & 4.0615 & 3.9718 & 4.0457 \\
\hline Sig. & .199 & .359 & .924 \\
\hline
\end{tabular}

Tab 6 Sorting comparison of the first 5 value scales of tourism enterprise employees and tourism-related college students

\begin{tabular}{|c|c|}
\hline & Sorting (mean) \\
\hline Student & 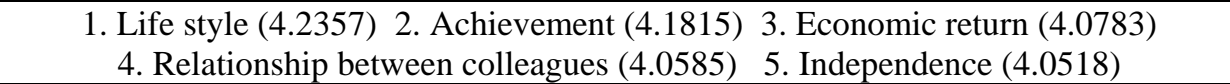 \\
\hline Employee & $\begin{array}{l}\text { 1. Achievement (4.3693) } 2 \text {. Relationship between colleagues (4.2348) 3. Supervision } \\
\text { relationship (4.2208) } 4 \text {. Life style (4.1802) 5. Reputation (4.1409) }\end{array}$ \\
\hline
\end{tabular}

Tab.7 Internal value dimension comparison of tourism enterprise employees and tourism-related college students

\begin{tabular}{|c|c|c|c|c|c|c|c|}
\hline Value scale & $\begin{array}{c}\text { Achieveme } \\
\mathrm{nt} \\
\text { mean }\end{array}$ & $\begin{array}{c}\text { Independen } \\
\text { ce } \\
\text { mean }\end{array}$ & $\begin{array}{c}\text { Altruism } \\
\text { mean }\end{array}$ & $\begin{array}{c}\text { Creativity } \\
\text { mean }\end{array}$ & $\begin{array}{c}\text { Sense of } \\
\text { beauty } \\
\text { mean }\end{array}$ & $\begin{array}{c}\text { Intelligence } \\
\text { stimulation } \\
\text { mean }\end{array}$ & $\begin{array}{c}\text { Manageme } \\
\text { nt } \\
\text { mean }\end{array}$ \\
\hline Student & 4.1815 & 4.0518 & 3.9032 & 3.8501 & 3.8390 & 3.8533 & 3.7952 \\
\hline Employee & 4.3693 & 4.1320 & 4.0216 & 4.0635 & 3.9911 & 3.9886 & 3.9315 \\
\hline Sig. & $.039^{*}$ & $.028^{*}$ & $.001^{* *}$ & .082 & .249 & .072 & .509 \\
\hline
\end{tabular}

Tab.8 External value dimension comparison of tourism enterprise employees and tourism-related college students

\begin{tabular}{|c|c|c|c|c|}
\hline Value scale & $\begin{array}{c}\text { Colleague relations } \\
\text { mean }\end{array}$ & $\begin{array}{c}\text { Supervision } \\
\text { relationship mean }\end{array}$ & $\begin{array}{c}\text { working } \\
\text { environment mean }\end{array}$ & Variability mean \\
\hline Student & 4.0585 & 4.0172 & 3.8232 & 3.6388 \\
\hline Employee & 4.2348 & 4.2208 & 3.7843 & 3.6472 \\
\hline Sig. & $.001^{* *}$ & $.033^{*}$ & .339 & .475 \\
\hline
\end{tabular}

Tab.9 External reward dimension comparison of tourism enterprise employees and tourism-related college students

\begin{tabular}{|c|c|c|c|c|}
\hline Value scale & Lifestyle mean & Reputation mean & $\begin{array}{c}\text { Economic } \\
\text { compensation mean }\end{array}$ & Safety mean \\
\hline Student & 4.2357 & 3.9853 & 4.0783 & 3.6930 \\
\hline Employee & 4.1802 & 4.1409 & 4.1307 & 3.7310 \\
\hline Sig. & .958 & .225 & .880 & .068 \\
\hline
\end{tabular}

\section{Discussion}

On the one hand, thins research assesses the influencing background of 3 dimensions and 15 scales; on the other hand, value scale valuing orders of employees and students are compared.

\subsection{Influence of internship situation, major and attitude to major on vocational values of tourism-related college students}

The survey shows that, the students with internship experience pay more attention to internal value of work in each value dimension, while the students without internship experience pay more attention to external remuneration. The possible reason is that internship experience makes students more profoundly understand the importance of work which brings people satisfaction. College students regard external remuneration as the most important factor in work, which indicates vocational values of current college students tend to utilitarianism and reality, and the ideal color weakens. 


\subsection{Influence of gender, position and post on vocational values of tourism enterprise employees}

The survey shows that; tourism enterprise employees of different gender have no significant difference on vocational values. For both tourism-related college students and tourism enterprise employees, their vocational values have no difference. Those with higher position pay more attention to internal value, and pay less attention to external value.

\subsection{Value dimension and scale comparison of tourism enterprise employees and tourism-related college students}

Tourism enterprise employees and tourism-related college students have no significant difference in consistency of value scale valuing degree, life style and economic return. This result is similar to the previous research results. It reveals that current vocational value orientation tends to utilitarianism and realism, and the ideal color weakens. Meanwhile, this also indicates that people's evaluation of vocational values has certain consistency in the general social environment and common culture background.

\section{Conclusion}

The major and the attitude to major will influence vocational values of tourism-related students. Position and post will influence vocational values of tourism enterprise employees.

The sorting (descending order) of each value scale in vocational values of tourism-related students is as follows: life style, achievement, economic return, relationship between colleagues, independence. The sorting (descending order) of each value scale in vocational values of tourism enterprise employees is as follows: achievement, relationship between colleagues, supervision relationship, life style, reputation. The vocational value differences between tourism enterprise employees and tourism-related students are mainly reflected in achievement, independence, altruism relationship between colleagues and supervision relationship.

\section{Acknowledgement}

Topic source: University-level topic of Guilin Tourism University "Comparative Study on Vocational Values of Tourism Enterprise Employees and College Students", No.: 2013YB12.

\section{References}

[1] Ning Weiwei, Research Review of Vocational Values, Social Psychology Research, 1991, (2).

[2] Yu Hua, Huang Xiting, Comparative Study on Vocational Values of College Students and Enterprise Employees in Mainland China, Psychological Science, 2000 (6)

[3] Ling Wenquan, Fang Liluo, Psychology and Behavior Measurement, China Machine Press, 2003.

[4] Wang Xingqiong, Empirical Study of Major Application Motivation of Tourism Majors on Their Learning Effect and Career Selection Tendency, Tourism Tribune, 2011. 